\title{
Anti-inflammatory Effects of Inhalation of Injured Starfish Extracts on Formaldehyde Exposure
}

\author{
Kyung Hee Hwang, Su Chan Chang, Jong Seok Park, Fazli Wahid and You Young Kim* \\ School of Life Sciences and Biotechnology, College of Natural Sciences, Kyungpook National University, Taegu 702-701, Korea
}

Received December 27, 2012 /Revised March 4, 2013 / Accepted April 19, 2013

\begin{abstract}
Formaldehyde (FA) is widely used in industries, and it is an indoor and outdoor pollutant. Exposure to FA may cause inflammation and respiratory oxidative stress. Studies have demonstrated that FA can cause cancer in animal models. During the regeneration process of injured starfish (Asterina pectinifera), several changes have been observed in the expression of cytokines. In particular, higher TGF- $\beta$ 1 expression has been detected in arm cut starfish extract after eight days. The current study was designed to elucidate the in-vitro and the in-vivo pharmacological effects of starfish extract on FA exposure. We investigated the protective effects of intact starfish extract and arm cut starfish extract on an IMR-90 cell line and on mouse lung injury in response to FA exposure. In the presence of FA, inhalation of the arm cut starfish extract was associated with more promising cell proliferation, TNF-a, $\mathrm{NF}-\kappa \mathrm{B}$ decrement, and Ik-Ba increment. In the experimental group, the pulmonary structure of the arm cut starfish extract-treated group in the presence of FA exposure was similar to the control group, whereas the FA exposure group showed damage to the pulmonary structure. Moreover, the arm cut starfish extracts was more effective than the intact starfish extracts in terms of the expression of TNF$a, N F-\kappa B, I \kappa-B a$, and surfactant protein $A$. The results obtained in this study demonstrate that arm cut starfish extracts are more effective in protecting pulmonary structure and function against FA exposure than intact starfish extracts.
\end{abstract}

Key words : Starfish, nebulizer, formaldehyde, inhalation, inflammation, anti-oxidants

\section{서 론}

휘발성 유기화합물(volatile organic compounds)에 의한 오 염은 사람에게 구토, 설사, 인후 자극 및 호흡곤란을 일으킨다 고 알려져 있다[13]. 휘발성 유기화합물 중 대표적 오염물질인 포름알데히드(formaldehyde, FA)는 자극적인 냄새가 나며 무 색의 수용성 기체로서, 요소계와 페놀계의 포름알데히드 합성 수지의 생산에 이용된다. 포름알데히드 합성수지는 파티클보 드, 섬유판, 베니아판 등을 생산할 때 접착제 및 발포 단열제로 서 가구, 건축 재료에 많이 포함되어 있으며 포름알데히드 수 지를 함유하고 있는 직물류에서도 발생할 수 있다[17, 22]. 이 러한 포름알데히드는 상부 기도, 눈 등의 점막과 피부에 자극 을 일으키며, 장기간 노출될 경우 호흡기계에 기침, 가래, 천 식, 만성 기관지염 등의 폐쇄성 폐질환 및 폐암의 발병과 관련 있다고 보고되어 있다[2, 5, 20].

폐는 호흡의 중추적 기관으로 독성이 있는 다양한 가스, 분

\footnotetext{
*Corresponding author

Tel : +82-53-950-6354, Fax : +82-53-943-2762

E-mail : yykim@knu.ac.kr

This is an Open-Access article distributed under the terms of the Creative Commons Attribution Non-Commercial License (http://creativecommons.org/licenses/by-nc/3.0) which permits unrestricted non-commercial use, distribution, and reproduction in any medium, provided the original work is properly cited
}

말 및 미량 액체에 노출이 되면 손상을 받아 폐 세포의 섬유화, Surfactant protein A (SP-A)의 감소 등으로 인한 각종 질병이 초래된다. 다양한 경로에 의해 유발되는 산화적 스트레스는 생체 안에 존재하는 항산화계에 의해 제거되지만 산화적 스트 레스가 항산화계의 수준을 초과하여 제거되지 못하면 염증 및 DNA 변형과 기능 상실에 의하여 퇴행성 질환이 유도된다 [11]. 염증은 외부의 자극이나 손상인자를 제거하기 위한 생체 방어로서 염증성 면역세포(T-cell, monocyte, macrophage), 혈 관내피세포(vesicular endothelial cell), 염증성 단백질 (inflammatory protein: cytokines, chemokines)이 관여하는 과정이다. 염증성 사이토카인으로 알려져 있는 tumor necrosis factor-a (TNF-a)는 염증의 주요한 매개자이고 정상 대 식세포에서 생성, 분비되며 세포사멸, 신생혈관 생성, 혈전을 유발하여 염증 과정에서 발현 정도가 증가된다. 또한 호중구 를 활성화시켜 과산화수소의 생성을 증가시키며 염증성 전구 물질들은 nuclear factor $\kappa \mathrm{B}(\mathrm{NF}-\kappa \mathrm{B})$ 와 같은 전사조절인자에 의해서 조절된다고 알려져 있다[26]. NF-kB는 유도성 전사인 자의 일종으로 염증을 포함한 다양한 병리학적 상태와 관련된 특이적 표적 유전자의 발현을 조절한다[25]. 전사인자인 NF-K $\mathrm{B}$ 는 세포질에서 이형이량체(heterodimer)나 동형이량체 (homodimer)를 이루면서 IKB라는 저해단백질(inhibitory protein)이 부착되어 불활성 상태로 존재한다[14]. 그러나 NF$\kappa \mathrm{B}$ 경로를 촉진하는 lipopolysaccharide (LPS), 염증성 사이토 
카인, 산화적 스트레스와 같은 다양한 세포외 신호를 받게 되 면 IkB가 분해되어 NF-kB를 활성화시켜 세포질에서 핵 내로 이동을 유도하고 $\mathrm{DNA}$ 와 결합하면서 염증성 전구물질을 생성 한다[26].

별불가사리(Asterina pectinifera)는 극피동물에 속하는 무척 추 해양생물로 steroid saponin과 sapogenin 등의 활성성분이 분리되는데 saponin은 sulphated sterol glycosides 등으로서 인삼 saponin (ginsenoside)들과 화학적 구조가 비슷하며 서식 장소에 따라 sulphated sterol glycosides 같은 다양한 스테로 이드 유도체로 항균 및 세포독성을 비롯한 미생물을 괴사시키 는 기능을 가지고 있음이 보고되었다 $[8,10,15,16,18,23,28]$. 불가사리를 포함한 모든 생물의 재생이나 상처 치유(wound healing) 과정에는 많은 성장 인자(growth factor)들이 작용을 하는 것으로 알려져 있다. 조직에 상처가 생기면 즉각적인 반 응으로 혈소판의 활성화가 일어나는데 혈소판은 transforming growth factor (TGF-: 형질전환 성장 인자)와 platelet derived growth factor (PDGF: 혈소판유도 성장 인자)를 포함 한 화학적인 인자들을 생성한다. 특히 TGF- $\beta$ 는 세포와 조직에 서 초기 발생의 조절, 세포주기의 조절, 세포 증식 및 분화, 세포외 기질의 생산, 면역 체계, 혈관 생성과 혈구세포 생산, 세포사 유도, 골격 형성, 상처 치유 등을 조절하는 다기능적인 cytokine으로 알려져 있다 $[1,6,19]$. 염증은 여러 가지 자극으 로 인해 국소에서 일어나는 복잡한 생체반응으로 외부의 자극 을 제거하고 조직의 손상에 대한 즉각적인 혈관반응인 동시에 신체의 재생기전이 시작되는 생체의 능동적인 방어기전이라 할 수 있다[7].

본 실험실에서 불가사리를 채집하여 조직을 손상시킨 후 1 일 단위로 수거하여 추출한 각각의 추출물을 섬유아세포인 osteoblast에 처리한 결과 조직손상 8 일째 추출물에서 TGF- $\beta$ 의 증가, $\mathrm{VEGF}$ 의 감소가 가장 현저하게 나타났다[27, 28]. 이 러한 결과는 불가사리 추출물이 염증의 완화를 통하여 조직재 생에 중요한 역할을 함을 알 수 있다. 이를 근거로 하여 본 연구에서는 조직손상 후 8 일이 경과한 불가사리 추출물을 포 름알데히드에 노출된 IMR-90에 처리하여 세포의 증식률과 염 증관련 전사인자인 TNF-a, NF-kB, Ik-Ba 발현에 미치는 영향 을 비교하였다. 또한 nebulizer를 이용하여 불가사리 추출물을 실험동물에 흡입시킴으로써 포름알데히드 노출에 의한 폐 기 능의 보호, 항 염증 효과, 폐 세포의 구조 변화 및 활성 산소종 으로 인한 세포 손상에 미치는 영향을 알아보고자 하였다.

\section{재료 및 방법}

\section{시약 및 장비}

$\mathrm{H}_{2} \mathrm{O}_{2}, \mathrm{NADPH}$, thiobarbituric acid (TBA), trichloroacetic acid (TCA), N-[2-Hydroxyethyl] piperazin- $\mathrm{N}^{\prime}$-[2-ethanesulfonic] acid (HEPES), ethylenediaminetetra-acetic acid
(EDTA), phenylmethane- sulfonyl fluoride (PMSF)는 SIGMA Chemical (St. Louis, USA), ammonium persulfate, sodium dodesyl sulfate (SDS), acrylamide, $\mathrm{N}, \mathrm{N}, \mathrm{N}^{\prime}, \mathrm{N}^{\prime}$-tetra methylene-diamine (TEMED), Bio-Rad protein assay kit는 Bio-Rad (Hercules, USA), methanol, ethanol, tween 20은 MERCK (Darmstadt, Germany)에서 구입하였다. TNF-a, NF-kB, Ik-B a, $\beta$-actin, surfactant protein $A$ 에 대한 항체는 SANTA CRUZ (Santa Cruz, USA), enhanced chemiluminescence (ECL), western blot detection kit는 AMERSHAM PHAMACIA BIOTECH (Oxford, UK), EDTA tube는 BD VACUTAINER (BD Vacutainer system, UK), hematoxyline, eosin xylene, autotechnicon, rotary microtome citadel-1000은 SHANDON (Shandon, Japan), marienfild histobond slide glass는 SUPERIOR (Superior, Germany)의 제품을 사용하였다.

\section{재료 및 채집}

본 연구는 동해안(경북 포항시 월포리) 연안에서 채집한 별 불가사리(Asterina pectinifera)를 사용하였으며 조직손상을 전 혀 주지 않은 불가사리와 방사대칭형의 팔 두 개를 절단한 후 8 일 동안 임대한 양어장에서 사육한 불가사리를 각각 채집 하여 $-20^{\circ} \mathrm{C}$ 에서 급속 냉동하였다.

\section{불가사리 추출}

냉동된 각각의 불가사리 $2 \mathrm{~kg}$ 을 $80 \%$ 에탄올 121 에 혼합하 여 $40^{\circ} \mathrm{C}$ 에서 6 시간 동안 $15 \mathrm{rpm}$ 조건으로 추출한 다음, 400 mesh, filter로 여과한 후 원심분리로 침전시켜 상층액을 다시 회전진공농축기(Laborota 4000, Heidolph, Japan)로 용매를 최대한 제거하였다 $[27,29]$. 농축된 추출물을 급속 냉동시킨 후 동결건조기(Neocool, Yamato, Japan)로 용매를 완전히 제 거하여 분말화하였다. 그 후 일정량을 3 차 증류수로 희석하여 $1 \mu \mathrm{m}$ 여과지(ADVANTEC, Japan)로 여과한 후 $\mathrm{pH}$ 7.4로 맞춘 불가사리 추출물(starfish crude extract, SCE)을 사용하였다.

\section{실험군 및 실험조건}

실험동물은 7주령 된 ICR 마우스(효창 사이언스)를 폴리프 로필렌 상자 $(453 \times 293 \times 247 \mathrm{~mm}, 19$ l) 안에 넣어 적정 사육조건 하에서 일반 고형사료(삼양사)와 물로 자유식이하면서 일주의 적응기간을 거쳐 실험에 사용하였다[11]. 실험 동물은 각각 7 마리씩 대조군(Control), 증류수만 처리한 군(Sham), 조직 손 상되지 않은 $\mathrm{SCE}$ 처리군(Int), 팔 절단 후 8 일이 경과한 $\mathrm{SCE}$ 처리군(8d), 조직이 손상되지 않은 SCE와 포름알데히드 처리 군(Int+FA), 팔 절단 후 8 일이 경과한 SCE와 포름알 데히드 처 리군 $(8 \mathrm{~d}+\mathrm{FA})$ 그리고 포름알데히드 처리군(FA)으로 나누었다 (Table 1).

예비실험에서 확인한 적정 농도의 $\mathrm{SCE}(0.5 \% / 50 \mathrm{ml} \mathrm{DDW})$ 를 8 시간 동안 one-jet nebulizer (MIDAS, H-30, Mega medi- 
Table 1. Experimental animals were divided into seven groups and each group was treated with following reagents

\begin{tabular}{ll}
\hline Group & Treatment \\
\hline Control & no (only fresh air) \\
Sham & deionized distilled water $(50 \mathrm{ml})$ \\
Int & $0.5 \%$ intact starfish extract $(50 \mathrm{ml})$ \\
Int+FA & $0.5 \%$ intact starfish extract $(50 \mathrm{ml})+5$ ppm FA exposure \\
$8 \mathrm{~d}$ & $0.5 \%$ arm cut starfish extract $(50 \mathrm{ml})$ \\
$8 \mathrm{~d}+\mathrm{FA}$ & $0.5 \%$ arm cut starfish extract $(50 \mathrm{ml})+5$ ppm FA exposure \\
FA & 5 ppm FA exposure \\
\hline
\end{tabular}

cal, Korea)를 이용하여 흡입시키고, 포름알데히드 흡입군은 포름알데히드(5 ppm)를 솜에 적신 그물망에 넣어 폴리프로필 렌 상자에 투입하여 동시에 흡입시켰다[4].

\section{세포주 및 실험조건}

본 실험에서 사용한 세포주는 사람유래 정상 섬유아세포인 IMR-90 (human lung fibroblast cell)을 사용하였고, ATCC (Manassas, VA, USA)에서 구입하였다. 각각의 실험군은 동물 실험과 동일하게 나누어 $10 \% \mathrm{FBS}$ 와 $1 \%$ penicillin/streptomycin이 첨가된 $\mathrm{DMEM}$ 배지에서 $5 \% \mathrm{CO}_{2}$ 존재 하의 $37^{\circ} \mathrm{C}$ 항온, 항습 $\mathrm{CO}_{2}$ incubator에서 배양하였다.

\section{MTT 분석}

세포독성은 세포증식을 측정하는 3-[4,5-dimethylthiazol-2yl]-2,5-diphenyltetrazolium bromide (MTT) assay를 이용하 였다. 각 세포의 증식속도를 고려하여 적정 수 $\left(5 \times 10^{4} \mathrm{cell} / \mathrm{ml}\right)$ 의 세포를 $1 \% \mathrm{FBS}$ 를 함유한 배지에 부유시켜 seeding하여 16 시간 starvation시킨 후, 불가사리 추출물과 예비실험을 통해 결정한 $3 \%(0.03 \mathrm{~g} / \mathrm{ml})$ 의 포름알데히드를 처리하였다. 시료 당 각각의 실험군은 96 well plate의 1 column (5-well)을 동일 한 조건으로 사용하였다. 여기에 $0.1 \mathrm{mg}$ MTT를 각 well에 첨가하여 3시간 배양하고 MTT를 환원시켜 생성된 포마잔 (formazan)을 DMSO와 EtOH가 1:1 섞인 용액 $150 \mu 1$ 를 가하 여 용해시킨 후 ELISA 후 $540 \mathrm{~nm}$ 에서 흡광도를 측정하였다.

\section{Catalase 활성측정}

$10 \mathrm{mM}$ phosphate buffer ( $\mathrm{pH}$ 7.0)에 $0.015 \mathrm{M} \mathrm{H}_{2} \mathrm{O}_{2}$ 를 가한 후 조직에서 추출한 단백질을 첨가하여 $240 \mathrm{~nm}$ 에서 흡광도를 측정하였다.

\section{지질과산화 측정}

지질과산화에 의해 생성되는 malondialdehyde 측정을 위 해 Thiobarvituric acid-reactive substance (TBARS)를 이용하 였다. 1 Volume sample에 2 Volume TBA용액( $0.375 \%$ TBA/ $15 \% \mathrm{TCA}$ in $0.25 \mathrm{~N} \mathrm{HCl}$ )을 가한 후 $15-20$ 분 동안 중탕하여
식힌 다음 $12,000 \mathrm{rpm}$ 에서 10 분간 원심분리하고 상층액을 취 하여 $535 \mathrm{~nm}$ 에서 흡광도를 측정하여 지질과산화 정도를 나타 내었다.

\section{단백질 발현 측정}

포름알데히드와 SCE를 시간대별로 전처리하고 세포를 수 거하였다. RIPA lysis buffer로 1시간 동안 균질화시킨 후 원심 분리하고 상층액을 획득하였다. 각각의 단백질 시료를 Bradford 방법으로 정량한 후 MTT 분석과 단백질 발현 실험에 사용하였다. $10 \sim 20 \mu \mathrm{g}$ 의 단백질을 $10 \%$ SDS-polyacrylamide gel 전기영동으로 분리한 후, nitrocellulose transfer membrane에 전이시켰다. 단백질이 전이된 membrane은 상온에서 2 시간동안 $5 \%$ skim milk로 blocking 시킨 후, 1 차 항체와 반응 시켰다. 1 차 항체반응은 TNF-a (1:1000), NF-kB (1:1000), Ik-Ba antibody (1:1000) 그리고 SP-A (1:2000)를 이용하여 $4{ }^{\circ} \mathrm{C}$ 에서 하룻밤 동안 수행하였다. 1차 항체반응이 끝난 membrane은 $0.1 \%$ Tween 20이 포함된 Tris-saline (TBS-T) 용액으로 세척한 후 2차 항체(1:2000)로 희석하여 2시간 동안 반응한 후 TBS-T 로 세척하였다. 단백질은 ECL detection kit로 반응시켜 X-ray 필름으로 결과를 검출하였다.

\section{폐의 채취 및 분리}

쥐의 복강에 PBS (phosphate-buffered saline), Zoletil, Rumpun을 12:2:1로 혼합한 마취제를 주사한 후 흥골 정중절 개술로 개흥하고 폐를 적출하여 Surgical blade로 다듬은 후 구조 관찰용 조직을 일부 취하고 나머지 조직은 sonication buffer (50 mM Tris-/ $\mathrm{HCl}$ (pH 7.5), 20 mM HEPES, $1 \mathrm{mM}$ EDTA, $2 \mathrm{mM}$ PMSF, 1\% Triton-X 100)에 옮겨 담아 ultrasonic generator sonication (US-50, Nissei, Tokyo, Japan)을 이용하 여 $4^{\circ} \mathrm{C}$ 에서 균질화하여 표본을 얻었다. 그 중 일부는 원심분리 없이 일정량을 취해 단백질을 정량하여 지질과산화 측정용으 로 사용하고, 나머지는 $4^{\circ} \mathrm{C}$ 에서 $15,000 \mathrm{rpm}$ 으로 15 분간 원심 분리하여 상층액을 $-70^{\circ} \mathrm{C}$ 에 보관하였다. 


\section{폐의 조직학적 관찰(H\&E stain)}

폐 조직을 10\% 포르말린에 24 48 시간 관류 고정한 후 수세 하여 일정한 크기로 잘라서 자동침투기(Shandon, Japan)를 거 친 다음 파라핀 블록을 만들어 Rotary Microtome (Shandon, Japan)으로 $4 \mu \mathrm{m}$ 두께로 자른 후 H\&E 염색 조건에 따라 염색 하여 광학현미경 $(100 \times)$ 으로 관찰하였다.

\section{통계 처리}

SPSS (Ver 11.5)를 이용하여 분석하였고 통계학적 의의는 $p<0.05$ 인 경우를 유의한 차이가 있는 것으로 판정하였다.

\section{결과 및 고찰}

\section{세포 증식효과}

예비실험에서 포름알데히드와 SCE를 처리한 후 $\mathrm{LD}_{50}$ 을 측 정한 결과 각각 적정 농도가 포름알데히드의 경우 $500 \mu \mathrm{M}$, $\mathrm{SCE}$ 의 경우 $0.0006 \mathrm{~g} / \mathrm{ml}$ 로 확인되었다. Fig. 1 은 포름알데히 드와 SCE를 처리한 후 MTT assay를 통한 세포의 증식 효과를 결과이다. 포름알데히드 처리군인 $8 \mathrm{~d}+\mathrm{FA}$ 군, Int+FA군과 FA 군은 Control군에 비해 세포의 증식이 감소하는 것을 확인할 수 있었는데 특히 FA만 처리한 군이 SCE를 함께 처리한 $8 \mathrm{~d}+\mathrm{FA}$ 군과 Int+FA군에 비해 세포증식이 큰 폭으로 감소됨을 알 수 있었다. 이는 포름알데히드가 세포증식을 억제시키는 반면에 SCE를 첨가함으로써 세포의 증식을 활성화시킴을 의 미하고 $8 \mathrm{~d}$ 추출물이 Int 추출물보다 포름알데히드 처리에 대 한 세포방어 작용에 더 효과적임을 확인하였다 $(p<0.05)$.

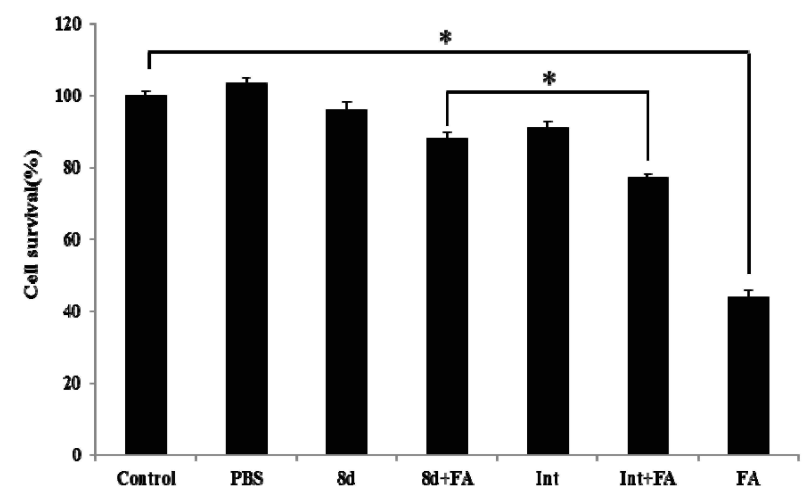

Fig. 1. Formaldehyde Effects of proliferation in IMR-90 cells. IMR-90 cells treated with formaldehyde $(50 \mu \mathrm{M})$ and intact star fish extract, formaldehyde and arm cut starfish extract, and only formaldehyde. IMR-90 cells $\left(5 \times 10^{4} / \mathrm{ml}\right)$ were incubated for $4 \mathrm{hr}$ at $37^{\circ} \mathrm{C}$ after treatments. The ordinate in figure is the relative value which means that the ratio of the control value to each group. Data are means $\pm \mathrm{SD}$ of six independent experiments for each group. ${ }^{*} p<0.05$ compared with control.

\section{세포 내 단백질 활성 측정}

Fig. 2는 SCE가 염증관련 전사인자인 TNF-a, NF-kB, Ik-Ba 발현에 미치는 영향에 대한 결과이다. TNF- $a$ 와 NF-kB 단백질 발현양이 Control군에 비해 Int군, Int+FA군, FA군에서는 크 게 증가하였으나 $8 \mathrm{~d}$ 군, $8 \mathrm{~d}+\mathrm{FA}$ 군에서는 큰 차이를 보이지 않 았다. 반면에 Ik-Ba의 경우, Control군에 비해 FA군에서 발현 양의 감소를 보였으나 $8 \mathrm{~d}$ 군, $8 \mathrm{~d}+\mathrm{FA}$ 군, Int군, Int+FA군에서는 큰 변화를 보이지 않았으며 $8 \mathrm{~d}+\mathrm{FA}$ 군이 Int+FA군보다 Ik-Ba 의 발현양이 더 증가되어 있음을 확인할 수 있었다. 이는 SCE 가 NF-kB가 핵으로 유입되지 않도록 $\mathrm{Ik}-\mathrm{Ba}$ 의 인산화 작용을 억제시켜 포름알데히드에 의한 염증 작용을 완화시키는 것으 로 알 수 있다.

\section{체중의 변화}

Fig. 3 은 실험기간에 따른 실험동물의 체중변화를 나타낸 결과이다. 각각의 실험군에서 체중 변화는 포름알데히드를 처 리하지 않은 Control군, Sham군, $8 \mathrm{~d}$ 군, Int군에서는 크게 차이 가 없었다. 반면에 포름알데히드를 처리한 $8 \mathrm{~d}+\mathrm{FA}$ 군, Int+FA 군, $\mathrm{FA}$ 군에서는 큰 감소가 확인되었는데 $\mathrm{SCE}$ 를 처리한 군에 서 1 주 후부터 증가됨을 알 수 있었고 4 주 후 $8 \mathrm{~d}+\mathrm{FA}$ 군이 Int+FA군보다 체중의 증가가 상대적으로 많음을 확인할 수 있었다. 이러한 결과는 포름알데히드 노출로 인한 체중의 감 소가 SCE의 흡입으로 인해 회복되는 것을 알 수 있다( $\beta \times 0.05)$.

\section{Catalase 활성}

Fig. 4 는 항산화 효소인 catalase의 활성을 측정한 결과이다. 포름알데히드 처리군인 $8 \mathrm{~d}+\mathrm{FA}$ 군, $\mathrm{Int}+\mathrm{FA}$ 군과 $\mathrm{FA}$ 군은

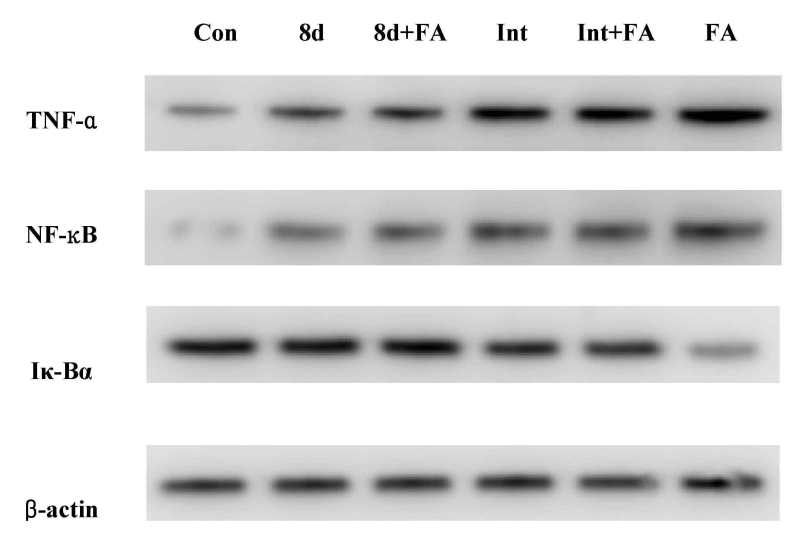

Fig. 2. The protein expression of TNF- $a, N F-\kappa B$, and Ik-Ba in IMR-90 cells with formaldehyde treatment or non-treatment. Samples were separated by SDS-PAGE and protein band were visualized by ECL. IMR-90 cells $\left(5 \times 10^{4} / \mathrm{ml}\right)$ were treated with formaldehyde and intact star fish extract, formaldehyde and eight days arm cut starfish extract, and only formaldehyde for $4 \mathrm{hr}$ at $37^{\circ} \mathrm{C}$. 


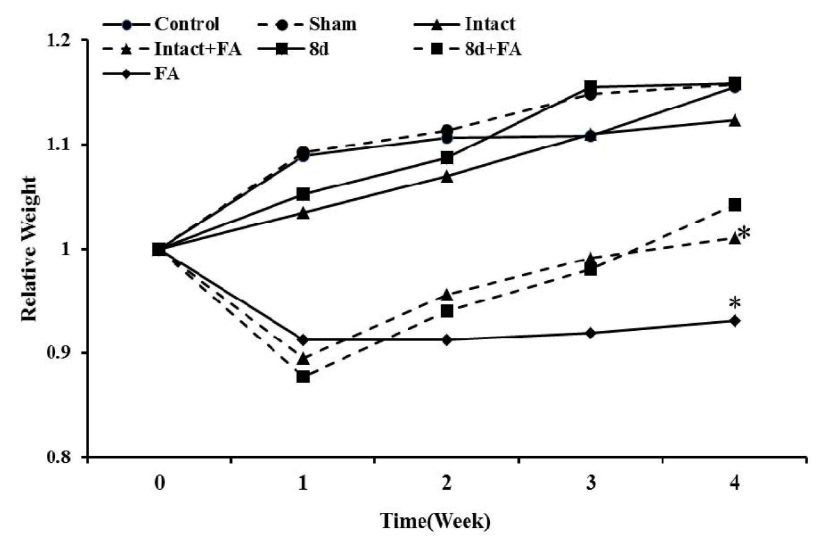

Fig. 3. Effects of formaldehyde inhalation on animal weight. For four weeks, the weight of each mouse was measured weekly at the same time. The ordinate in figure is the relative value which means the ratio of the control value to each group. Data are means \pm SD of 7 mice per group. ${ }^{*} p<0.05$. compared with control.

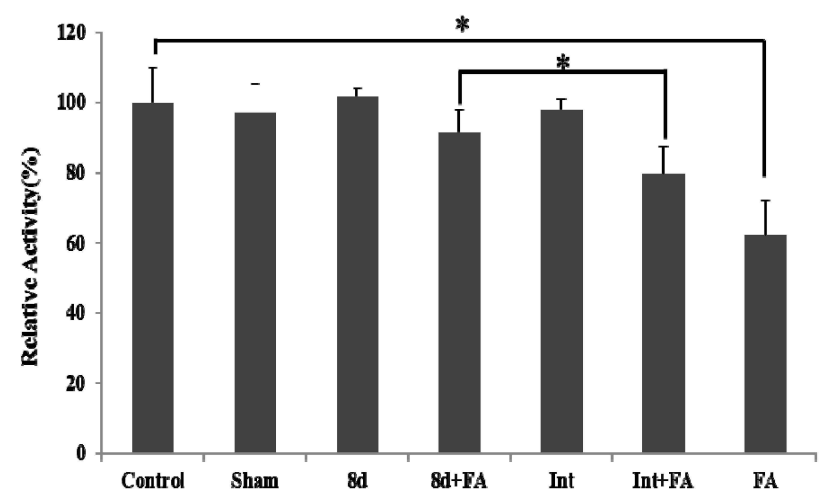

Fig. 4. The catalase enzyme activity in formaldehyde exposed or unexposed animals. Experimental animals were exposed to formaldehyde, formaldehyde and intact star fish extract, formaldehyde and eight days arm cut starfish extract inhalation for 4 weeks. The ordinate in figure is the relative value which means the ratio of the control value to each group. Data are means \pm SD of 7 mice per group. ${ }^{*} p<0.05$ compared with control.

Control군에 비해 catalase의 활성이 전반적으로 감소하는 것 을 확인할 수 있었다. SCE를 함께 처리한 $8 \mathrm{~d}+\mathrm{FA}$ 군과 $\mathrm{Int}+\mathrm{FA}$ 군이 $\mathrm{FA}$ 만 처리한 군에 비해 활성이 증가되었으며 특히 $8 \mathrm{~d}+\mathrm{FA}$ 군이 Int+FA군보다 비교적 증가폭이 크게 나타났다. 이 는 $\mathrm{SCE}$ 가 포름알데히드에 의하여 catalase의 활성이 억제되는 것을 방어하고 항산화 효소의 활성을 유지시킨다고 할 수 있 다 $(p<0.05)$.

\section{지질과산화 측정}

Fig. 5는 세포막의 지질과산화 정도를 측정하여 나타낸 결 과이다. 포름알데히드 처리군인 $8 \mathrm{~d}+\mathrm{FA}$ 군, $\mathrm{Int}+\mathrm{FA}$ 군과 $\mathrm{FA}$ 군

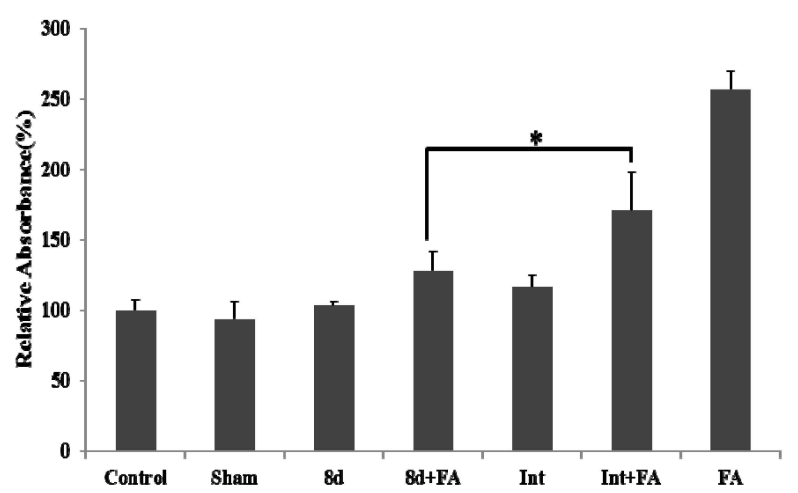

Fig. 5. Lipid peroxidation of lung tissue in formaldehyde exposed or unexposed animals. Experimental animals were exposed to formaldehyde, formaldehyde and intact star fish extract, formaldehyde and eight days arm cut starfish extract inhalation for 4 weeks. The level of malondialdehyde accumulated in the isolated lung tissues were determined by using TBARS assay. The ordinate in figure is the relative value which means the ratio of the control value to each group. Data are means \pm SD of 7 mice per group. ${ }^{*} p<0.05$ compared with control.

은 Control군에 비해 지질과산화가 전반적으로 증가하는 것을 확인할 수 있었다. SCE를 함께 처리한 $8 \mathrm{~d}+\mathrm{FA}$ 군과 $\mathrm{Int}+\mathrm{FA}$ 군 이 $\mathrm{FA}$ 만 처리한 군에 비해 지질과산화 생성이 상대적으로 감 소되었고 또한 $8 \mathrm{~d}+\mathrm{FA}$ 군이 $\mathrm{Int}+\mathrm{FA}$ 에 비해 지질과산화가 비교 적 적게 일어남을 확인할 수 있었다( $p<0.05)$. 이는 SCE를 처리 함으로써 포름알데히드 흡입으로 인한 지질과산화 작용에 대 한 예방효과 및 손상으로부터 세포막을 보호한다는 것을 알 수 있다.

\section{혈액성분의 변화}

Table 2는 포름알데히드와 SCE의 흡입이 백혈구에 미치는 영 향을 확인한 결과이다. 호중구(nuetrophil), 림프구(lymphocyte), 단핵구(monocyte), 호산구(eosiniphil)의 분석에서, 포름알데 히드를 처리한 $8 \mathrm{~d}+\mathrm{FA}$ 군, $\mathrm{Int}+\mathrm{FA}$ 군과 $\mathrm{FA}$ 군은 Control군에 비 해 백혈구가 증가하였으며 $8 \mathrm{~d}+\mathrm{FA}$ 군과 Int+FA군은 FA군보다 백혈구 증가폭이 낮았으며, 또한 $8 \mathrm{~d}+\mathrm{FA}$ 군이 Int+FA군에 비해 백혈구의 증가폭이 적었다 $(p<0.05)$. 이는 $8 \mathrm{~d}$ 추출물이 Int 추출 물보다 더 효과적인 항염증 작용을 함을 알 수 있다. 호중구와 호산구에서 $\mathrm{FA}$ 군의 증가가 많이 일어난 것을 보아 포름알데 히드 흡입이 염증관련 폐질환을 일으키는 요소로 작용할 수 있음을 알 수 있다.

\section{실험동물 조직 내 단백질 활성 측정}

Fig. 6은 폐 조직에서의 TNF-a, NF- $\kappa \mathrm{B}, \mathrm{I} \kappa-\mathrm{Ba}$ 와 SP-A의 발 현 정도를 확인한 결과이다. 동물실험에서도 IMR-90에 포름 알데히드 및 $\mathrm{SCE}$ 를 처리한 것과 유사한 결과가 나왔다. 즉 
Table 2. The effects of formaldehyde exposure and star fish extracts treatment on white blood cell $\left({ }^{*} p<0.05\right)$

\begin{tabular}{|c|c|c|c|c|c|c|c|c|}
\hline \multirow[b]{3}{*}{ Con } & \multirow{2}{*}{\multicolumn{2}{|c|}{$\begin{array}{l}\text { Lymphocyte } \\
\text { Value } \pm S D\end{array}$}} & \multirow{2}{*}{\multicolumn{2}{|c|}{$\begin{array}{l}\text { Neutrophil } \\
\text { Value } \pm S D\end{array}$}} & \multirow{2}{*}{\multicolumn{2}{|c|}{$\begin{array}{l}\text { Monocyte } \\
\text { Value } \pm \text { SD }\end{array}$}} & \multirow{2}{*}{\multicolumn{2}{|c|}{$\begin{array}{l}\text { Eosinophil } \\
\text { Value } \pm \text { SD }\end{array}$}} \\
\hline & & & & & & & & \\
\hline & 1.00 & 0.05 & 1.00 & 0.09 & 1.00 & 0.08 & 1.00 & 0.05 \\
\hline Sham & 1.03 & 0.02 & 0.93 & 0.04 & 0.98 & 0.17 & 1.07 & 0.10 \\
\hline $8 \mathrm{~d}$ & 1.03 & 0.07 & 1.06 & 0.08 & 0.98 & 0.10 & 1.02 & 0.06 \\
\hline $8 \mathrm{~d}+\mathrm{FA}$ & 1.05 & 0.05 & $1.17^{*}$ & 0.08 & 1.15 & 0.05 & 1.23 & 0.06 \\
\hline Int & 1.09 & 0.02 & 1.14 & 0.06 & 1.18 & 0.08 & 1.10 & 0.14 \\
\hline Int+FA & 1.14 & 0.02 & $1.40^{*}$ & 0.09 & 1.44 & 0.29 & 1.36 & 0.08 \\
\hline FA & 1.21 & 0.09 & 1.73 & 0.19 & 1.75 & 0.13 & 1.89 & 0.08 \\
\hline
\end{tabular}

The value is the relative value which means the ratio of the control value to each group. Result presents the value \pm SD of 7 mice per group. * $p<0.05$ compared with control group.

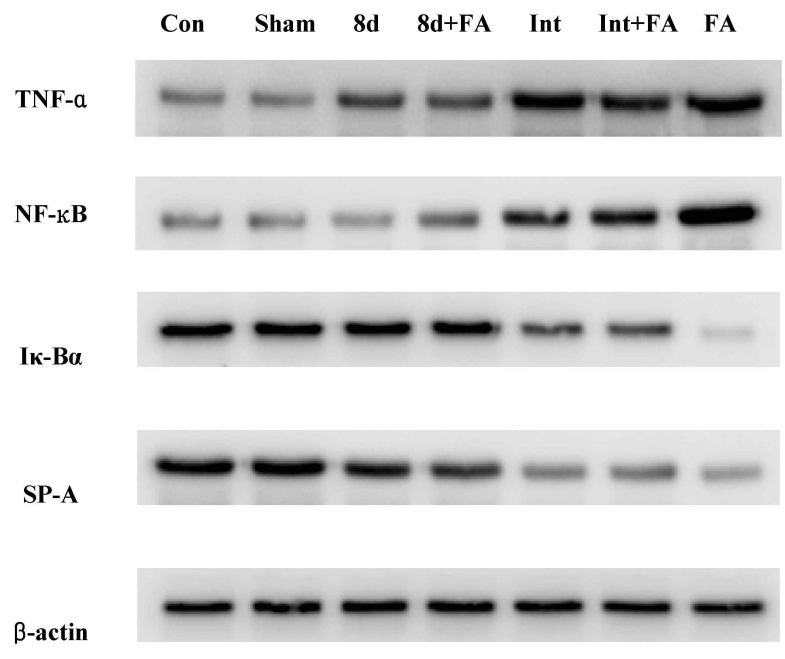

Fig. 6. The expression of TNF-a, NF-kB and Ik-Ba, SP-A proteins in lungs tissue. Experimental animals were exposed to formaldehyde, formaldehyde and intact star fish extract, formaldehyde and eight days arm cut starfish extract inhalation for 4 weeks. Samples were separated by SDS-PAGE and protein band were visualized by ECL.

TNF- $a$ 와 NF- $k B$ 단백질 발현양이 Control군에 비해 Int군, $\mathrm{Int}+\mathrm{FA}$ 군, $\mathrm{FA}$ 군에서는 크게 증가하였으나 Sham군, $8 \mathrm{~d}$ 군, $8 \mathrm{~d}+\mathrm{FA}$ 군에서는 큰 증가를 보이지 않았다. 반면에 $\mathrm{Ik}-\mathrm{Ba}, \mathrm{SP}-\mathrm{A}$ 의 경우, Control군, Sham군, $8 \mathrm{~d}$ 군, $8 \mathrm{~d}+\mathrm{FA}$ 군에서는 유사하게 나타났으나 FA군, Int군, Int+FA군은 Control군에 비해 현저 히 감소된 발현양을 확인할 수 있었다. $8 \mathrm{~d}+\mathrm{FA}$ 군이 Int+FA군 보다 $\mathrm{Ik}-\mathrm{Ba}, \mathrm{SP}-\mathrm{A}$ 의 발현양이 더 증가되어 있음을 확인할 수 있었다. 따라서, $8 \mathrm{~d}$ 추출물이 Int 추출물보다 포름알데히드로 인한 SP-A의 감소를 효과적으로 방어함을 알 수 있다.

\section{폐 조직의 변화}

Fig. 7은 4 주 동안 실험한 후 각 실험군의 동물에서 얻은 폐 조직을 $\mathrm{H \& E}$ 염색 결과이다. Control군의 폐포 구조는 배열 이 규칙적으로 정상적인 구조로 관찰되었다. 이에 반해 FA군
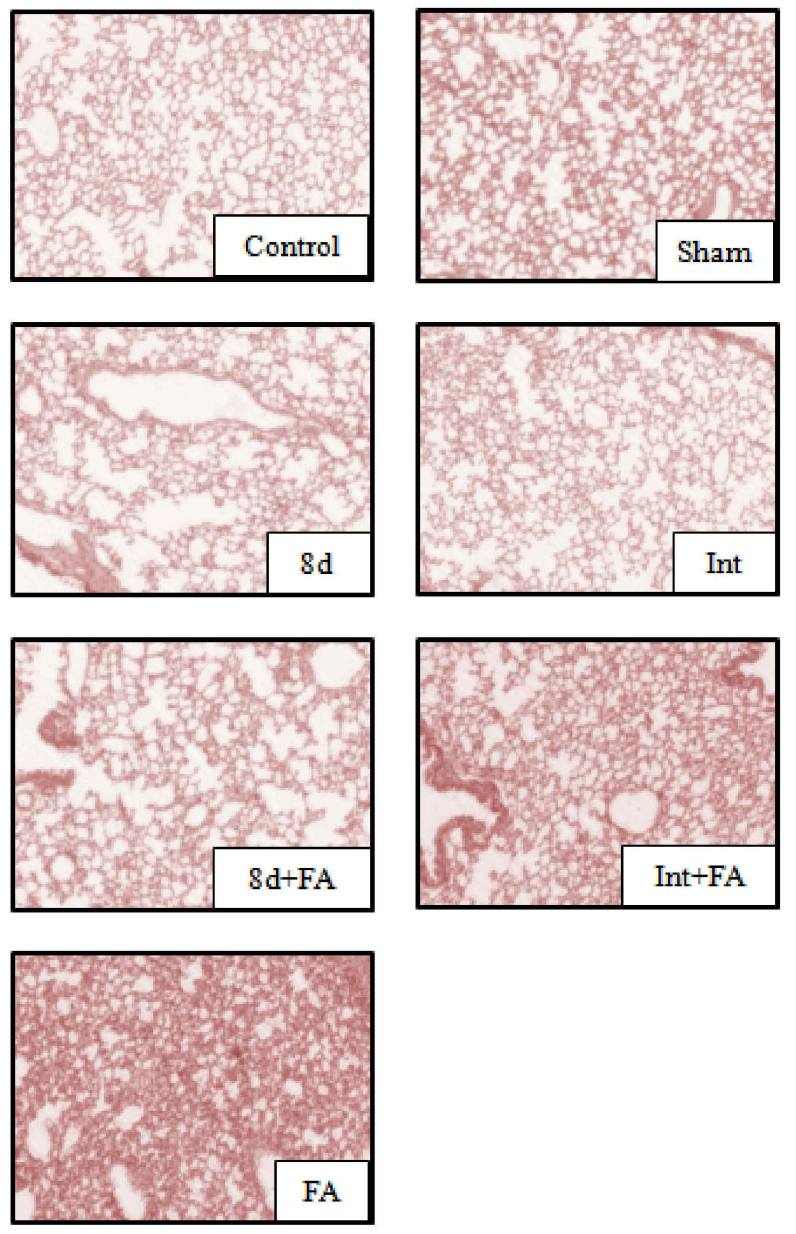

Fig. 7. The structure and morphology of the lungs tissue. Experimental animals were exposed to formaldehyde, formaldehyde and intact star fish extract, formaldehyde and eight days arm cut starfish extract inhalation for 4 weeks. The H\&E staining were performed and pictures were taken at $100 \times$ magnification in microscope.

은 폐포의 공간이 불규칙하며 폐포벽 사이의 심한 유착과 함 께 두꺼워졌으며, 폐 세포의 수가 많아 졌음을 관찰할 수 있었 다. 그 외에 Sham군과 $8 \mathrm{~d}$ 군, Int군은 Control군과 비슷한 형태 
를 나타냈으며, $8 \mathrm{~d}+\mathrm{FA}$ 군과 Int+FA군은 폐포 공간이 약간 불 규칙하게 커지고 폐포벽이 약간 두꺼워져 있을 뿐 다른 구조 적 변화는 관찰할 수 없었다. Int+FA군보다 $8 \mathrm{~d}+\mathrm{FA}$ 군에서 조 직의 방어효과가 있음을 확인할 수 있다. 이러한 결과는 $8 \mathrm{~d}$ 추출물이 포름알데히드 흡입으로 인한 유해물질로부터 폐 조 직을 보호하며, 그 자체로는 조직과 세포 내에 영향을 미치지 않음을 알 수 있다.

\section{결 론}

본 연구의 선행 실험에서 흡연에 노출된 세포주와 동물실험 을 통하여 불가사리 추출물이 항염증 효과가 있음을 확인한 바 있다[9]. 이에 대한 심화 연구로 본 실험은 조직손상을 전혀 주지 않은 불가사리와 팔 두 개를 절단한 후 8 일 동안 사육한 불가사리로부터 crude extract를 추출하여 환경오염물질로 알 려진 포름알데히드에 노출된 IMR-90에 처리하거나 ICR 마우 스에 nebulizer를 이용하여 흡입시켜 불가사리 추출물의 항염 증 작용을 확인하였다.

포름알데히드에 노출된 IMR-90에 조직손상 후 8 일이 경과 한 SCE 처리한 결과, 유의한 세포 증식을 보였으며 염증 조절 에 영향을 주는 TNF- $\mathrm{a}, \mathrm{NF}-\mathrm{kB}$ 의 발현억제 및 $\mathrm{Ik}-\mathrm{Ba}$ 의 합성을 촉진시켰다.

포름알데히드에 노출된 ICR 마우스에 조직손상 후 8 일이 경과한 $\mathrm{SCE}$ 를 처리한 결과, 체중의 증가, 항산화 효소의 증가, 지질과산화의 감소, surfactant protein A의 증가, TNF-a 및 $\mathrm{NF}-\kappa \mathrm{B}$ 의 발현억제, $\mathrm{Ik}-\mathrm{Ba}$ 의 발현 증가를 통한 항염증과 조직 재생에 더 우수한 효과를 보였다. 포름알데히드에 의한 체중 의 경우 사육 초기에는 이전의 연구결과에 보고된 것처럼 체 중의 감소가 나타났으나[30] 기간이 경과함에 따라 회복됨을 확인하였다. 생체 내에는 각종 요인에 의해 생성된 유해 라디 칼을 효과적으로 제거하기 위해 여러 항산화 효소 및 항산화 제가 존재하며, 항산화 효소의 작용에 의하여 만들어진 $\mathrm{H}_{2} \mathrm{O}_{2}$ 는 catalase에 의해 물로 변환된다. 또한, 세포를 둘러싸고 있는 세포막의 주된 성분인 인지질은 산화손상에 의해 지질과산화 물을 생성하며 이는 생체 내 산화손상의 지표가 된다[30]. 본 실험에서 항산화 효소인 catalase의 경우, Int+FA군보다 $8 \mathrm{~d}+\mathrm{FA}$ 군에서 활성의 감소가 적게 일어닜으며 지질과산화의 경우 $\mathrm{Int}+\mathrm{FA}$ 군보다 $8 \mathrm{~d}+\mathrm{FA}$ 군에서 지질과산화의 정도가 낮음 을 확인하였다. 염증반응에 관여하는 혈액성분에 있어서 $8 \mathrm{~d}+\mathrm{FA}$ 군보다 Int+FA군에서 백혈구의 수치가 상대적으로 증 가하였으며, TNF-a, NF- $\mathrm{BB}$ 의 발현이 억제되었으며, 이는 이 전 연구결과와 동일한 효과를 보여 주었다[3]. Ik-Ba와 폐의 숙주방어와 염증반응에 중요하게 관여하는 것으로 알려진 $\mathrm{SP}-\mathrm{A}$ 단백질의 경우[24], $\mathrm{FA}$ 군보다 $8 \mathrm{~d}$ 군과 $8 \mathrm{~d}+\mathrm{FA}$ 군에서 분 해가 억제되어 더 많이 발현됨을 확인할 수 있었다. 또한 손상 된 불가사리 추출물에 포함된 성장인자가 포름알데히드 흡입
시 발생하는 폐의 구조적 손상으로부터 기능과 구조의 항상성 을 유지하는데 효과를 주며[21], 특히, 포름알데히드로 유도되 는 폐세포의 비정상적인 형태 변화 및 폐포벽의 두꺼워짐과 폐포 공간의 불규칙적인 변화로부터 조직 구조와 기능의 항상 성을 유지시킴으로 염증의 진행을 억제하는 것으로 사료된다. 이상의 결과를 통해, 불가사리 추출물은 환경오염인자인 포름 알데히드에 의한 항염증 효과를 가지고 있음을 알 수 있으며, Int군보다 $8 \mathrm{~d}$ 군에서 그 효과가 더 우수함을 확인하였다. 하지 만 IMR-90 cell line을 이용한 세포실험(Fig. 2)과 ICR 마우스를 사용한 동물실험(Fig. 6)에서 추출물을 단독으로 처리한 Int군, $8 \mathrm{~d}$ 군이 TNF-a, NF- $\mathrm{kB}$ 의 발현증가 및 $\mathrm{Ik}-\mathrm{Ba}$ 의 합성 감소를 보였는데 이는 순수 정제되지 않은 crude extracts를 사용한 결과라고 예상된다. 따라서, 불가사리 추출물에 포함된 TGF- $\beta$ 에 의한 작용 $[21,22]$ 이외에 다른 저분자들을 통한 항염증 효 과인지를 확인하기 위하여 앞으로의 연구에서 단일 물질만을 정제하거나 또는 추출물 속에 포함된 물질을 따로 분리, 정제 하여 그 효과를 확인하여야 할 것이다.

\section{References}

1. Böttner, M., Krieglstein, K. and Unsicker, K. 2000. The transforming growth factor-betas: structure, signaling, and roles in nervous system development and functions. J Neurochem 75, 2227-2240.

2. Callas, P. W., Pastides, H. and Hosmer, D. W. Jr. 1996. Lung cancer mortality among workers in formaldehyde industries. J Occup Environ Med 38, 747-748.

3 . Cazzola, M., Page, C. P., Calzetta, L. and Matera, M. G. 2012. Emerging anti-inflammatory strategies for COPD. Eur Respir J 40, 724-741.

4. Chuck, Y. and Derrick, C. 1998. A review of the emission of VOCs from polymeric materials used in buildings. Build Environ 33, 357-374.

5. Collins, J. J., Acquavella, J. F. and Esmen, N. A. 1997. An updated meta-analysis of formaldehyde exposure and upper respiratory tract cancers. I Occup Environ Med 39, 639-651.

6. Dünker, N. and Krieglstein, K. 2000. Targeted mutations of transforming growth factor-beta genes reveal important roles in mouse development and adult homeostasis. Eur $J$ Biochem 267, 6982-6988.

7. Herold, S., Mayer, K. and Lohmeyer, J. 2011. Acute lung injury:how macrophages orchestrate resolution of inflammation and tissue repair. Front Immunol 2, DOl: 10.3389/fimmu.2011.00065.

8. Hideki, K., Kenji, H. and Seiichi, A. 2006. Characteristics of carboxypeptidase B from pyloric ceca of the starfish Asterina pectinifera. Food Chemistry 95, 264-269.

9. Hwang, K. H., Jung, H,. Chang, S. C., Park, J. S. and Kim, Y. Y. 2012. The Injured Starfish Extract Inhalation Effects of Anti-inflammation and Anti-oxidants Enzyme during Indirect Cigarette Smoking. KSBB J 27, 367-374. 
10. Iriyama, N., Takeuchi, N., Shiraishi, T., Izumi, K., Sawada, M. T., Takahashi, N., Furuhata, K., Ogura, H. and Uda, Y. 2000. Enzymatic properties of sialidase from the ovary of the starfish, Asterina pectinifera. Comp Biochem Physiol B Biochem Mol Biol 126, 561-569.

11. Jung, H. 2004. Inhalation effects of natural product extracts in mouse lung against cigarette smoking and formaldehyde exposure. Doctor Thesis. The Graduate School of Kyungpook National University.

12. Kamdar, O., Le, W., Zhang, J., Ghio, A. J., Rosen, G. D. and Upadhyay, D. 2008. Air pollution induces enhanced mitochondrial oxidative stress in cystic fibrosis airway epithelium. FEBS Lett 582, 3601-3606.

13. Kampa, M. and Castanas, E. 2008. Human health effects of air pollution. Environ Pollut 151, 362-367.

14. Kang, J. H. 2004. Studies on the anti-inflammatory and anti-metastatic properties of soybean saponins. Master Thesis. The Graduate School of Ulsan University.

15. Kishimura, H. and Hayashi, K. 2002. Isolation and characteristics of trypsin from pyloric ceca of the starfish Asterina pectinifera. Comp Biochem Physiol B Biochem Mol Biol 132, 485-490

16. Kishimura, H. and Ando, S. 2007. Characteristics of phospholipase A2 mutant of the starfish Asterina pectinifera. Enzyme Microb Technol 40, 461-465.

17. Kita, T., Fujimura, M., Myou, S., Ishiura, Y., Abo, M., Katayama, N., Nishitsuji, M., Yoshimi, Y., Nomura, S., Oribe, Y. and Nakao, S. 2003. Potentiation of allergic bronchoconstriction by repeatedexposure to formaldehyde in guinea-pigs in vivo. Clin Exp Allergy 33, 1747-1753.

18. Lee, D. W., Sohn, H. O., Lim, H. B., Lee, Y. G., Aprikian, A. G. and Aprikian, G. V. 1995. Antioxidant action of Ginseng: An hypothesis. Korea J Ginseng Sci 19, 31-38.

19. Linkhart, T. A., Mohan, S. and Baylink, D. J. 1996. Growth factors for bone growth and repair: IGF, TGF beta and BMP. Bone 19, 1-12.

20. Marsh, G. M., Stone, R. A., Esmen, N. A., Henderson, V. L. and Lee, K. Y. 1996. Mortality among chemical workers in a factory where formaldehyde was used. Occup Environ Med 53, 613-627.

21. Monfared, A. L. 2012. Histomorphological and ultrastructural changes of the placenta in mice exposed to formaldehyde. Toxicol Ind Health [Epub ahead of print].

22. Nakazawa, H., Ikeda, H., Yamashita, T., Hara, I., Kumai, Y., Endo, G. and Endo, Y. 2005. A case of sick building syndrome in a Japanese office worker. Ind Health 43, 341-345.

23. Nam, K. Y. 2002. Clinical applications and efficacy of Korea ginseng (Panax ginseng C.A. Meyer). J Ginseng Res 26, 111-131.

24. Nayak, A., Dodagatta-Marri, E., Tsolaki, A. G. and Kishore, U. 2012. An Insight into the diverse roles of surfactant proteins, SP-A and SP-D in innate and adaptive immunity. Front Immunol 3, 131.

25. Pikarsky, E., Porat, R. M., Stein, I., Abramovitch, R., Amit, S., Kasem, S., Gutkovich-Pyest, E., Urieli-Shoval, S., Galun, E. and Ben-Neriah, Y. 2004. NF-kapppaB function as tumor promotor in inflammation-association cancer. Nature 431, 461-466.

26. Plutzky, J. 2001. Inflammatory pathway in atherosclerosis and acute coronary syndrome. Am J Cardiol 88, 10-15.

27. Shin, D. C. 2003. Effects of arm cut Asterina pectinifera extracts on human keratinocyte and mouse fibroblast cells proliferation. Master Thesis. The Graduate School of Kyungpook National University.

28. Shin, J. Y., Choi, E. H. and Wee, J. J. 2001. The Difference of ginsenoside compositions according to the conditions of extraction and fractionation of crude ginseng saponins. Korean J Food Sci Technol 33, 282-287.

29. Sung, M. Y. 2003. Effect of injured starfish extract on growth factors and cell proliferation. Master Thesis. The Graduate School of Kyungpook National University.

30. Wang, F., Li, C., Liu, W., Jin, Y. and Guo, L. 2013. Effects of subchronic exposure to low-dose volatile organic compounds on lung inflammation in mice. Environ Toxicol 10, 1002. 
초록 : 손상된 불가사리 추출물 흡입이 포름알데히드 노출에 의한 항염증 작용에 미치는 효과

황경희 · 장수찬 · 박종석 · 와히드 파즈리 · 김유영*

(경북대학교 자연과학대학 생명공학부)

포름알데히드는 주로 산업용으로 사용되는 독성이 강한 물질로서 생체에 노출 시 염증, 산화적 스트레스, 알레 르기 반응, 나아가서 암을 유발하게 된다. 불가사리에서 추출되는 saponin은 sulphated sterol glycosides 등으로 서 인삼 saponin (ginsenoside)들과 화학적 구조가 비슷하여 항균 및 세포독성을 비롯한 미생물을 괴사시키는 기 능을 가지고 있음이 보고되었다. 또한 손상된 불가사리의 조직에는 염증성 사이토카인이 발현되는데 TGF- $\beta$ 의 증가로 손상 받은 부위를 빠르게 치료, 재생하게 된다. 본 실험은 조직손상 후 8 일 된 불가사리 추출물과 포름알 데히드를 IMR-90에 처리했을 때와 포름알데히드에 노출시킨 ICR 마우스에 불가사리 추출물을 흡입시켰을 때 염증성 폐 손상의 방어 및 치료에 미치는 효과를 알아보았다. 포름알데히드에 노출된 IMR-90에 조직손상 후 8 일 이 경과한 불가사리 추출물을 처리한 결과, 세포의 유의한 증식을 보였으며 염증 조절에 영향을 주는 TNF-a, NF$\kappa \mathrm{k}$ 의 발현억제 및 $\mathrm{Ik}-\mathrm{Ba}$ 의 합성을 촉진시켰다. 포름알데히드에 노출된 ICR 마우스에 조직손상 후 8 일이 경과한 불가사리 추출물을 처리한 군에서 체중의 증가, 항산화 효소의 증가, 지질과산화 작용의 감소, surfactant protein $\mathrm{A}$ 의 증가, TNF-a 및 NF-kB의 발현억제, Ik-Ba 발현의 증가와 조직재생에 우수한 효과를 보였다. 이러한 결과는 포름알데히드로 인한 세포 및 폐 손상을 불가사리 추출물의 항염증 작용을 통하여 억제하거나 완화시킴을 확인 할 수 있다. 